\title{
A THURSTONE MÓDSZER ÁLTALÁNOSÍTÁSAI
}

\author{
MIHÁLYKÓ CSABA, MIHÁLYKÓNÉ ORBÁN ÉVA, GYARMATI LÁSZLÓ
}

\begin{abstract}
Páros összehasonlításokat gyakran alkalmaznak a döntéshozatalban, a véleményezések során, de páros összehasonlításoknak tekinthetjük sportmérkőzések végeredményeit is. Az összehasonlítások eredményeinek kiértékelésére többféle módszer alkalmazható. Az egyik ilyen eljárás a Thurstone módszer, amely az egyes kiértékelt objektumok mögé látens valószínüségi változót illeszt, így valószínüségszámítási alapon értékeli ki az objektumokat. Ez alkalmas több döntési kategória alkalmazására valamint előny, illetve hátrány beépítésére. Cikkünkben egy olyan általános modellt fogalmazunk meg, amely tetszőleges számú kategóriát tud kezelni, nem specifikált eloszlásokat használ és magában foglalja az esetlegesen meglévő előnyt, illetve hátrányt. Modellünket alkalmazzuk futballbajnokság eredményeinek kiértékelésére.
\end{abstract}

\section{Bevezetés}

Páros összehasonlításokat gyakran alkalmaznak különféle területeken. Történetileg a pszichológiai értékelések skálázásának szubjektivitása okán adódott Thurstone azon korszakalkotó ötlete, amely szerint a kiértékelések során érdemes páronként összehasonlítani az objektumokat, s az így kialakult véleményeket valamilyen módszerrel kiértékelni. Az ő elgondolása szerint az objektumok erősségei valószínüségi változók, amiknek a különbségéről mondanak véleményt az összehasonlítás során ([1]). Thurstone kétfajta véleményt engedett meg, az egyik az erösebb (jobb), a másik az ellentettje, a gyengébb (rosszabb). Gyakran azonban több kategóriát is célszerű figyelembe venni, például az egyformát (sportban a döntetlent), vagy a sokkal erősebb (sokkal jobb)/sokkal gyengébb (sokkal rosszabb) kategóriákat. Rendkívül népszerü az ilyen jellegü módszerek között az Analytic Hierarchy Process (AHP) módszer, ami Saaty nevéhez kapcsolódik ([2]). Ennél a módszernél az egyes objektumok összehasonlításakor végső soron azt adjuk meg, hogy az egyik objektumot hányszor gondoljuk jobbnak a másiknál. Saaty az 1, 3, 5, 7 és 9 faktorokat használta. Az $i$-dik és $j$-dik objektum összehasonlításakor így kapott $a_{i j}$ számokból felépített páros összehasonlítási mátrix legnagyobb sajátértékéhez tartozó sajátvektorának koordinátái szolgáltatták nagyság szerint rendezve az objektumok sorrendjét. A módszernek vitathatatlanul sok előnye mellett vannak 
hátrányai is. Csak teljes összehasonlítás mellett (vagyis amikor minden objektum minden objektummal össze van hasonlítva) lehet alkalmazni, szubjektív és így kissé nehézkes a szorzófaktorok helyes megállapítása az egyes összehasonlításkor, ami ráadásul gyakran vezet inkonzisztenciához. A nemteljesség problémáját többféleképpen fel lehet oldani, utalunk itt Bozóki és szerzőtársai cikkére és az abban található releváns irodalomra ([3]). Az inkonzisztencia kérdéskörével pedig többek között Temesi összefoglaló cikke és több, benne hivatkozott cikk foglalkozik ([4]), de található ebben a cikkben a nemteljességgel kapcsolatos hivatkozás is. További hátrány, ami a mostani cikkünk kapcsán releváns, hogy az esetleges előny beépítése az AHP keretén belül nem megoldott. Thurstone módszerébe azonban ez az általánosítás beépíthetö.

A Thurstone módszer esetében az egyes véleményeknek a számegyenesen egyegy intervallumot feleltethetünk meg, például két kategória esetén a jobb azt jelenti, hogy a látens valószínűségi változók különbsége pozitív (a megfelelő sorrendben kivonva őket), a rosszabb pedig azt, hogy ez a különbség negatív. Három kategória alkalmazásakor az egyforma (döntetlen) esetében a különbség egy nulla körüli szimmetrikus intervallumba esik, a rosszabb az intervallum alsó vége alatti értéket, a jobb az intervallum felső végét meghaladó különbséget jelenti. (Megjegyezzük, hogy a módszer esetében ezt az értéket is az adatok alapján becsüljük, vagyis nem önkényesen jelöljük ki a kategóriák intervallumhatárait). Ez a felfogás könnyen általánosítható. Az egyes intervallumokba esés valószínüsége alapján a valószínüségi változók várható értéke meghatározható, ezek sorrendje adja az objektumok sorrendjét.

Thurstone normális eloszlást alkalmazott a látens valószínüségi változókra, a Bradly-Terry modellben logisztikus eloszlást alkalmaznak ([5]), Stern gamma eloszlásokkal dolgozott ([6]), de ezeket nagymértékben általánosíthatjuk szigorúan logkonkáv sürüségfüggvénnyel rendelkező eloszlások alkalmazásával ([7]). Jelen cikkünkben ezt az eloszlásfüggvény típust használjuk.

Általános jelenség, hogy - például a sportban, vagy tenderek elbírálásánál bizonyos körülmények előnyt biztosíthatnak az egyik fél számára. Ilyen a sakkban a kezdés lehetősége, csapatsportoknál a hazai pálya előnye. Ezt a jelenséget kívánjuk oly módon beépíteni Thurstone továbbfejlesztett módszerébe, hogy az egyúttal alkalmas legyen arra, hogy jelezze az előny meglétét anélkül, hogy azt a priori feltételeznénk, és adott esetben kimutassa és számszerüsítse a jelenlétét, ha az valóban létezik. Ezt a következő feltételezésre alapozva hajtjuk végre: az előny folytán az előnyben levő objektum várható értéke megnő, hátrány esetén lecsökken. Ez alapján lehetőség nyílik arra, hogy a növekedés, illetve csökkenés mértéke újabb paraméterek bevezetésével jellemezhető legyen. Ez a megközelítés már a legegyszerủbb, úgynevezett konstans előnyös formában három kategória esetére ki lett dolgozva ([8]), most azonban olyan módon általánosítjuk, amikor minden egyes objektum esetében bevezetünk egy-egy, az objektumra jellemző előnyt, illetve hátrányt megadó paramétert. Ezen új paraméterek becslése után már számszerüsíthe- 
tővé válik az előny mértéke, és például ez a számszerüsített érték figyelembe vehető az egyes objektumok összehasonlítási eredményei valószínüségének számolásakor.

Cikkünkben a 2. fejezetben ismertetjük az általános modellt, majd kitérünk a megoldás egyértelmü létezésének feltételeire a 3. fejezetben, a 4. fejezetben alkalmazzuk módszerünket futballbajnokság eredményeinek kiértékelésére. Végül egy összefoglalóval zárjuk cikkünket.

\section{Az általános modell}

Jelölje $n$ a kiértékelendő objektumok számát, magukat az objektumokat jelöljék az $1,2, \ldots, n$ számok. Ezek az objektumok páronként össze vannak hasonlítva akár véleményezők által, akár sportmérkőzések eredményei által. Mi a megfogalmazásunkban az első változatot fogjuk használni.

Gondolatban képzeljünk minden objektum mögé egy látens valószínüségi változót. Az objektumról alkotott vélekedés egy véleményező szemében egy adott pillanatban egy véletlen mennyiség, amely időben is, de a körülményektől függően is változhat, továbbá ugyanazt az objektumot más-más ember másként értékeli. Jelölje az $i$-edik objektum mögé képzelt valószínüségi változót $\xi_{i}, i=1,2, \ldots, n$ és legyen a várható értékük $m_{i}, i=1,2, \ldots, n$. Az objektumok átlagos erösségét a valószínüségi változók várható értéke jellemzi, ezek nagyság szerinti sorrendje adja az objektumok sorrendjét is. Az összehasonlítás során $s \quad(2 \leq s)$ féle véleményt engedünk meg, jelöljük ezeket $C_{1}, C_{2}, \ldots, C_{s}$-sel, és nevezzük őket (vélemény)kategóriáknak. Ezek a kategóriák például: rosszabb/egyforma/jobb $s=3$ esetén. Több kategória esetén az elnevezések tovább bővülnek. Ezek a kategóriák kizárják egymást, továbbá teljesül rájuk egyfajta szimmetria: például ha $i$ jobb $j$-nél, akkor $j$ rosszabb $i$-nél. A kategóriák számszerüsítése érdekében a kategóriáknak intervallumokat feleltetünk meg a következőképpen: a valós számok halmazát $(\mathbb{R})$ felbontjuk $s$ diszjunkt intervallumra, ezeket jelöljük $I_{i}$-vel, $i=1,2, . ., s$, ahol $I_{j} \cap I_{k}=\oslash$, ha $j \neq k$, és $\mathbb{R}=I_{1} \cup I_{2} \cup \ldots \cup I_{s}$. Ha az $i$-edik és a $j$-edik objektum összehasonlításának eredménye $C_{k}$, akkor a $\xi_{i}-\xi_{j}$ különbség az $I_{k}$ intervallumba esik. Az intervallumokat meghatározzák a végponjaik, ezeket $-\infty=a_{0}<a_{1}<a_{2}<\ldots<a_{s-1}<a_{s}=\infty$-nel jelöljük. $I_{1}=\left(a_{0}, a_{1}\right)$, $I_{k}=\left[a_{k-1}, a_{k}\right), k=2, \ldots, s$, valamint $a_{i}=-a_{s-i}$. Világos, hogy ha $s$ páros, akkor $a_{\frac{s}{2}}=0$. A kategóriák és a nekik megfeleltetett intervallumok az 1 . ábrán láthatók.

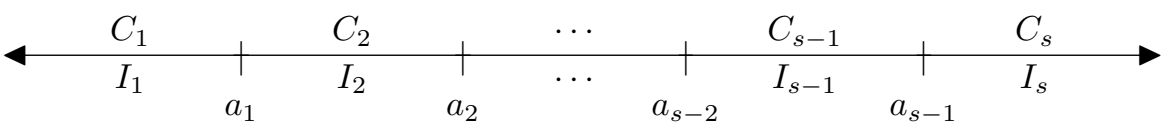

1. ábra. A kategóriák és a nekik megfeleltetett intervallumok 
Az egyes kategóriák kialakulásának, azaz a különbség adott intervallumokba való esésének valószínűsége a $\xi_{i}-\xi_{j}$ valószínüségi változó eloszlásfüggvénye segítségével kiszámolható. Ha a $\xi_{i}$ valószínúségi változókat az alábbi alakban írjuk, $\xi_{i}=m_{i}+\xi_{i}^{\prime}$, akkor $\xi_{i}^{\prime}$ már nulla várható értékü valószínüségi változó lesz, és $\xi_{i}-\xi_{j}=m_{i}-m_{j}+\xi_{i}^{\prime}-\xi_{j}^{\prime} \cdot \xi_{i}^{\prime}-\xi_{j}^{\prime}$ (és egyben $\xi_{i}-\xi_{j}$ ) eloszlását Thurstone normális eloszlásnak feltételezte, mi most ezeket általános, kétszer folytonosan differenciálható szigorúan logkonkáv sűrűségfüggvénnyel rendelkező eloszlásfüggvényekre általánosítjuk. Vagyis előny figyelembe vétele nélkül

$$
\xi_{i}-\xi_{j}=m_{i}-m_{j}+\xi_{i}^{\prime}-\xi_{j}^{\prime},
$$

ahol $\xi_{i}^{\prime}-\xi_{j}^{\prime}$ eloszlásfüggvénye $i, j i \neq j$ pár esetén $F_{i j}$.

Az előny, illetve a hátrány azt jelenti, hogy az előnyben levő objektum várható értéke egy rá jellemző konstanssal megnő, a hátrányban levőé pedig egy rá jellemző konstanssal lecsökken. Jelölje ezeket $e_{i}$ illetve $h_{i}, i=1,2, \ldots, n$. Feltételezzük, hogy az összehasonlított objektumok egyike előnyben, másika hátrányban van egy összehasonlítás során. Természetesen beépíthető lenne az is, ha létezne semleges összehasonlítás, vagy olyan eset, amikor az egyik előnye nem vonná maga után a másik hátrányát, de ezekkel az esetekkel jelen publikációban nem foglalkozunk. ket):

Ekkor (1) a következőképpen módosul (a felső indexszel jelöltük a körülménye-

$$
\begin{aligned}
& \xi_{i}^{e}-\xi_{j}^{h}=m_{i}+e_{i}-\left(m_{j}-h_{j}\right)+\xi_{i}^{\prime}-\xi_{j}^{\prime} ; \\
& \xi_{i}^{h}-\xi_{j}^{e}=m_{i}-h_{i}-\left(m_{j}+e_{j}\right)+\xi_{i}^{\prime}-\xi_{j}^{\prime} .
\end{aligned}
$$

Természetes feltételezés lenne $0 \leq e_{i}, 0 \leq h_{i}, i=1,2, \ldots, n$, azonban nem élünk ilyen feltevésekkel. Előfordul ugyanis, hogy az előnynek gondolt körülmény a tapasztalat alapján mégsem az. Mivel megengedjük az $e_{i}=0$ és $h_{i}=0$ értékeket, ezért ez a modell az előnyt figyelembe nem vevő modell általánosítása.

Legyen $r$ a véleményezők száma. Az $u$-adik véleményező véleménye $(u=$ $1,2, \ldots, r)$ az $i$-edik és a $j$-edik objektum összehasonlításakor $(i<j)$ mind az $i$-edik objektum előnye, mind az $i$-edik objektum hátránya esetén egy-egy $s$ dimenziós vektor, amelynek minden koordinátája 0 vagy 1 , és azon koordináta egyenlő 1-gyel, ahányadik kategóriát mondja a megfigyelő véleményként. A megfigyelésekből alkotott mátrix tehát egy négydimenziós $X$ mátrix, amelynek elemei $i=1,2, \ldots, n-1, j=i+1, \ldots, n, k=1,2, \ldots, s, u=1,2, \ldots, r$ esetén

$$
X_{i, j, k, u}^{e}=\left\{\begin{array}{c}
1, \text { ha az u-adik véleményezö véleménye } C_{k} \\
i \text { és } j \text { összehasonlítása és } i \text { elönye esetén } \\
0, \text { különben }
\end{array}\right.
$$


és

$$
X_{i, j, k, u}^{h}=\left\{\begin{array}{c}
1, \text { ha az u-adik véleményező véleménye } C_{k} \\
i \text { és } j \text { összehasonlítása és } i \text { hátránya esetén } \\
0, \text { különben }
\end{array}\right.
$$

Ha $j \leq i$, akkor a mátrixelemek legyenek 0 értéküek. Természetesen előfordulhat, hogy $X_{i, j, k, u}^{e}=0$ és/vagy $X_{i, j, k, u}^{h}=0$ minden $k=1,2, \ldots, s$ esetén, ha $i<j$. Ez azt jelenti, hogy az $u$-adik véleményező nem hasonlította össze az $(i, j)$ párt $i$ előnye és/vagy hátránya esetén. Az $e$, illetve a $h$ felső index itt is az előnyre, illetve a hátrányra utal. Ha mindkét érték nulla minden $u$ esetén, akkor egyáltalán nem történt összehasonlítás a két objektum között. Megjegyezzük, hogy ez még nem feltétlenül akadálya a sorrend eldöntésének.

Legyenek $A_{i, j, k}^{e}=\sum_{u=1}^{r} X_{i, j, k, u}^{e}$ és $A_{i, j, k}^{h}=\sum_{u=1}^{r} X_{i, j, k, u}^{h}$, vagyis ahány vélemény esetén a $C_{k}$ kategória alakul ki $i$ elönyös, illetve hátrányos helyzetében a véleményezések során. Annak a valószínűsége, hogy ez a minta alakul ki, független véleményeket feltételezve a következő:

$$
\begin{aligned}
& L\left(X^{e}, X^{h} \mid m_{1}, m_{2}, \ldots, m_{n}, a_{1}, \ldots, a_{s-1}, e_{1}, e_{2}, \ldots, e_{n}, h_{1}, h_{2}, \ldots, h_{n}\right)= \\
& =\prod_{k=1}^{s} \prod_{i=1}^{n-1} \prod_{j=i+1}^{n}\left(P\left(\xi_{i}^{e}-\xi_{j}^{h} \in I_{k}\right)\right)^{A_{i, j, k}^{e}} \cdot\left(P\left(\xi_{i}^{h}-\xi_{j}^{e} \in I_{k}\right)\right)^{A_{i, j, k}^{h}} .
\end{aligned}
$$

A paraméterek maximum likelihood becslése az a $3 n+s-1$ dimenziós vektor, amely a (4) függvényt maximalizálja az $\underline{m}=\left(m_{1}, \ldots, m_{n}\right),\left(a_{1}, a_{2}, \ldots, a_{s-1}\right)$, $\left(e_{1}, e_{2}, \ldots, e_{n}\right),\left(h_{1}, h_{2}, \ldots, h_{n}\right)$ változókban az $a_{i}=-a_{s-i}, i=1,2, \ldots, s-1$ feltételek mellett. Az $F_{i j}(-\infty)=0$ és $F_{i j}(\infty)=1$ jelölésekkel élve

$$
\begin{gathered}
P\left(\xi_{i}^{e}-\xi_{j}^{h} \in I_{k}\right)=P\left(a_{k-1} \leq \xi_{i}^{e}-\xi_{j}^{h}<a_{k}\right)= \\
=F_{i j}\left(a_{k}-\left(m_{i}+e_{i}-\left(m_{j}-h_{j}\right)\right)\right)-F_{i j}\left(a_{k-1}-\left(m_{i}+e_{i}-\left(m_{j}-h_{j}\right)\right)\right), \\
P\left(\xi_{i}^{h}-\xi_{j}^{e} \in I_{k}\right)=P\left(a_{k-1} \leq \xi_{i}^{h}-\xi_{j}^{e}<a_{k}\right)= \\
=F_{i j}\left(a_{k}-\left(m_{i}-h_{i}-\left(m_{j}+e_{j}\right)\right)\right)-F_{i j}\left(a_{k-1}-\left(m_{i}-h_{i}-\left(m_{j}+e_{j}\right)\right)\right),
\end{gathered}
$$

amiket (4)-be helyettesítve a paraméterek maximum likelihood becslése

$$
\begin{gathered}
\left(\widehat{m}_{1}, \ldots, \widehat{m}_{n}, \widehat{a}_{1}, \ldots, \widehat{a}_{s-1}, \widehat{e}_{1}, \ldots, \widehat{e}_{n}, \widehat{h}_{1}, \ldots, \widehat{h}_{n}\right)= \\
=\underset{(\underline{m}, \underline{a}, \underline{e}, \underline{h}),-\infty<a_{1}<a_{2}<\ldots<a_{s-1}<\infty, a_{i}=-a_{s-i}}{\arg \max } L\left(X^{e}, X^{h} \mid \underline{m}, \underline{a}, \underline{e}, \underline{h}\right) .
\end{gathered}
$$

ahol $\underline{a}=\left(a_{1}, a_{2}, \ldots, a_{s-1}\right), \underline{e}=\left(e_{1}, e_{2}, \ldots, e_{n}\right), \underline{h}=\left(h_{1}, h_{2}, \ldots, h_{n}\right)$. 


\section{A maximum likelihood becslés létezése és egyértelmüsége}

Természetesen a páros összehasonlítások kiértékelése érdekében nagyon fontos, hogy a likelihood függvénynek, illetve a logaritmusának létezzen a maximuma és az egyértelmü legyen.

Mivel látható, hogy mind (5), mind (6) pozitívak, azért (4) értékei pozitívak, így a likelihood függvény helyett annak logaritmusa vizsgálható. A két függvény maximuma egyszerre létezik, és a maximumhely egyértelmüsége egyszerre teljesül. A log-likelihood függvény vizsgálatakor a szorzótényezőkből összeadandók lesznek, a kitevők szorzótényezőkké szelídülnek, s ha nincs megfelelő összehasonlítási eredmény, az összegből az annak megfelelő tag hiányzik.

Mivel a likelihood függvény csak a várható értékek különbségétől függ, ezért az egyik várható érték rögzíthető, például $m_{1}=0$. Azonban ekkor is könnyü olyan példát mutatni, amikor a maximumhely nem létezik, vagy nem egyértelmü ([9]). A log-likelihood függvény maximumának létezése a paraméterhalmaz korlátos zárt halmazra való szúkíthetőségén múlik. Az egyértelműség bizonyításának alapötlete pedig az, hogy a sürüségfüggvények szigorú logkonkávitása biztosítja az eloszlásfüggvények szigorú logkonkávitását ([10]), valamint ezek alapján az $F(x, y)=F(x)-F(y)$ kétváltozós függvény szigorú logkonkávitását mindkét változóban ([7]). A szigorúan logkonkáv függvények maximuma pedig ha létezik, akkor egyértelmü.

A [7] publikációban $\underline{e}=\underline{0}, \underline{h}=\underline{0}, a_{k}-a_{k-1}=2 d, k=2,3, \ldots, s-1$ feltételek mellett adtunk elégséges feltételt a maximum létezésére és a helyének egyértelmüségére. A [11] publikáció szintén előny és hátrány figyelembe vétele nélkül, $s=2,3,4,5$ kategória esetén ad feltételeket az egyértelmü létezésre normális eloszlású látens valószínüségi változókat feltételezve, de nem feltétlenül egyforma hosszúságú intervallumok esetén. Ezek az esetek a gyakorlati problémák kezelésekor többnyire elegendőnek bizonyulnak. A [8] publikációban három kategória megengedésével, minden objektumnál egyforma előny és ugyanakkora hátrány megengedésével mutattunk be a paraméterek becslésének egyértelműségét biztosító elégséges feltételt. Általános $s$ esetén nem tudunk megfogalmazni elégséges feltételt a (4) függvény maximumának egyértelmű létezésére, de az egyenlő osztásközök feltételezése mellett, ha az objektumok esetén ugyanakkora mértékű az előny, mint a hátrány, de ezek objektumonként különbözhetnek, akkor az előnyt és hátrányt megengedő modellben az alábbi állítás fogalmazható meg. Az előny és a hátrány egyforma mértéke az általánosság korlátozása nélkül feltételezhető.

Legyen $e_{i}=h_{i}, i=1,2, \ldots, n$. Ez azt jelenti, hogy az előnyben levő $i$ objektum várható értéke $e_{i}+e_{j}$ többlettel rendelkezik $j$-vel szemben.

Definiáljunk egy $G$ gráfot az alábbi módon. A gráf csúcsai az értékelendő objektumok. Az $i$-edik és a $j$-edik $(i<j)$ csúcs akkor legyen összekötve, ha van köztük összehasonlítás mind $i$ előnyös, mind $i$ hátrányos helyzete esetén, továbbá

$$
0<A_{i, j, k}^{e} \text { valamely } 1<k<s \text { esetén, vagy } 0<A_{i, j, 1}^{e} \cdot A_{i, j, s}^{e}
$$


és

$$
0<A_{i, j, k}^{h} \text { valamely } 1<k<s \text { esetén, vagy } 0<A_{i, j, 1}^{h} \cdot A_{i, j, s}^{h} \text {, }
$$

azaz (8) és (9) mindegyike teljesül. Megjegyezzük, hogy (8) és (9) azt fejezi ki, hogy elönyben is és hátrányban is nem csak egyoldalú szélső helyzetü döntés születik. Ekkor az alábbi tétel bizonyítható ([12]):

3.1. TÉTEL. Legyenek $F_{i j}$-k olyan eloszlásfüggvények, amelyre $0<F_{i j}(x)<1$ teljesül, háromszor folytonosan differenciálhatók $\mathbb{R}$-en, valamint sürüségfüggvényük nullára szimmetrikus és logaritmusa szigorúan konkáv. Legyen $3 \leq s$. Tegyük fel, hogy van olyan $i_{1}<j_{1}$ pár, amelyre $0<A_{i_{1}, j_{1}, k}^{e}+A_{i_{1}, j_{1}, k}^{h}$, valamely $1<k<s$ esetén, valamint van olyan $i_{2}<j_{2}$ és $k<l-1$ pár, amelyre $0<A_{i_{2}, j_{2}, k}^{e} \cdot A_{i_{2}, j_{2}, l}^{e}$ vagy $0<A_{i_{2}, j_{2}, k}^{h} \cdot A_{i_{2}, j_{2}, l}^{h}$ teljesül. Legyen $\underline{e}=\underline{h}$. Rögzítsük az $m_{1}$ értékét nullának. Amennyiben az elözőekben definiált $G$ gráf összefüggö, valamint nem fa, akkor (4) függvény a $0<d=a_{k}-a_{k-1}, a_{k}=-a_{s-k} k=2, \ldots, s-1, a_{0}=-a_{s}=-\infty$ feltételek mellett felveszi a maximumát az $\underline{m}, d$ és $\underline{e}$ változókban, és a maximumhely egyértelmü.

A tételben szereplő $\left(i_{1}, j_{1}\right)$ és $\left(i_{2}, j_{2}\right)$ párokra vonatkozó két feltétel azt mondja ki, hogy legalább egy párnál van „nem szélsőséges” döntés, valamint van olyan pár, amelynél van két egymást nem követő intervallumba eső döntés akár előnyös, akár hátrányos helyzetben. Ez a két feltétel azt biztosítja, hogy a $d$ paraméterben való optimalizálás korlátos, zárt halmazra szükíthető. (8) és (9) együtt biztosítják a gráfban szereplő élekhez tartozó indexpárok esetén az $m_{i}-m_{j}$ valamint az $e_{i}+e_{j}$ mennyiségek korlátosságát. A gráf összefüggösége $m_{1}=0$ mellett az $m_{i}$ értékek $i=1,2, \ldots, n$ korlátosságát is eredményezi. Mindezekből következik a maximum létezése.

Megjegyezzük, hogy a korlátosságot úgy is biztosíthatjuk, ha egy összefüggo” részgráfhoz kapcsolunk elemeket például közbülső intervallumba eső eredményekkel mind előnyben, mind hátrányban, azonban a kapcsolódás különböző elemekhez is történhet. A szigorú logkonkávitás gyengébb feltételek mellett is teljesül, elegendő hozzá (8) és (9) feltételek vaggyal való összekapcsolása, de szükséges, hogy mind előnyben, mind hátrányban legyen mérkőzés. Az a feltétel, hogy legyen kör a gráfban amiatt szükséges, hogy az egyértelmüen meghatározott $e_{i}+e_{j}$ értékekböl az $e_{i} i=1,2, \ldots, n$ kifejezhetö legyen.

Megjegyezzük, hogy két kategória megengedése esetén analóg állítás mondható ki. A d-beli optimalizálás okafogyottá válik, így kevesebb paramétert használunk. Az $s=2$ miatt értelmezhetetlenné váló feltételeket elhagyva a gráf az előzőeknek megfelöen definiálandó, az egyértelmüség elégséges feltétele a gráf összefüggősége mellett az, hogy ne legyen fa. 


\section{Alkalmazás}

Az előnyt figyelembe vevő modell alkalmazását mutatjuk be egy példán, esetünkben a magyar labdarúgó bajnokság első osztálya (OTP Bank Liga) 2019/20-as szezonjának eredményeire. Azzal az implicit feltételezéssel élünk, hogy a csapatok minden mérkőzés esetében a tölük telhető legjobb eredményre törekszenek.

A bajnokságban 12 csapat vett részt. Az elönyt a haza pálya jelentheti. Bár esetünkben mindenki játszott mindenkivel előnyben és hátrányban is, mégis a kiértékelések eredménye nem feltétlenül létezik: ha például valamelyik csapat minden mérkőzését megnyerte volna, az ML becslés kiértékelésének eredménye nem létezne. A likelihood függvény ugyanis nem venné fel a maximumát, mert amennyiben a csapathoz tartozó valószínüségi változó várható értéke nő, a likelihood függvény értéke is nő. Vagyis a sorrend megállapítható lenne, de a csapat jósága nem lenne számszerúsíthető. Ebben a bajnokságban azonban nem ez az eset áll fenn.

Az adatokat a [13] honlapról töltöttük le.

A modellek esetén $s=3$ kategóriát engedtünk meg, a vereség, a döntetlen és a győzelem, mint eredmény kifejezésére. Ez esetben egy közbülső intervallum és két szélső intervallum van a számegyenesen, egy paraméter $(0<d)$ segítségével jelöljük ki a határaikat.

Minden csapat esetén ugyanakkora előnyt feltételeztünk, mint hátrányt, vagyis $e_{i}=h_{i}, i=1,2, \ldots n$. A különbségek eloszlását normálisnak választottuk 1 szórással, vagyis $F_{i j}(x)=\Phi(x)$. A $T$-vel jelölt modellben $e_{i}=h_{i}=0, i=1,2, \ldots, n$. A $T^{K E}$-vel jelölt modellben $e_{i}=h_{i}=x$, azaz minden csapatnak egyforma előnyt jelentett a hazai pálya. A $T^{D E}$-vel jelölt modellben $e_{i}=h_{i}=x_{i}, i=1,2, \ldots, n$ de az $x_{i}$ értékek egymástól különbözhettek. Ez esetben más-más csapatok különbözőképpen profitálhatnak a hazai pálya körülményéből.

A paraméterek ML becslése $m_{1}=0$ rögzítése után egyértelmü. Mivel az alfabetikus sorrendben a Debrecen van elöl, ezért ezt a csapatot jelöltük az 1-es számmal.

Az előny nélküli Thurstone módszer esetén $\widehat{d}=0,334$, a $T^{K E}$ modell esetén $\widehat{d}=0,337$, a $T^{D E}$ modell esetén $\widehat{d}=0,350$, vagyis az egyforma kategória határai nagyon közel esnek egymáshoz.

A pontszámok alapján az első négy helyezett kiemelkedik, az 5-10. hely pontszámai tömörülést mutatnak, a 12. helyezett Kaposvár nagyon leszakadt (lsd 1. Táblázat 2. oszlopa).

Látható, hogy a csapatok sorrendjeiben az egyes kiértékelések között nincs nagy különbség. Az első négy csapat minden kiértékelés szerint ugyanaz, mint ahogy a két utolsó is. Az is látható, hogy amint a szerzett pontokat tekintve, úgy az átlagos erősség tekintetében $\left(\widehat{m}_{i}\right)$ is kiemelkedő a Ferencváros és leszakadó a Kaposvár. A tömörülésben mutatkoznak az eltérések a kiértékelési eredmények között. A $T, T^{K E}$ módszer esetén az első eltérés az Újpest és a Zalaegerszeg (6. hely és 7 . hely) között látható. Pontszámban a kettő csapat ugyanannyit ért el, 


\begin{tabular}{|l|c|c|c|c|c|c|c|c|}
\hline \multicolumn{2}{|c|}{ Csapatok } & \multicolumn{2}{c|}{$T$} & \multicolumn{2}{c|}{$T^{K E}$} & \multicolumn{3}{c|}{$T^{D E}$} \\
\hline \multicolumn{1}{|c|}{ hivatalos sorrend } & pont & & $\widehat{m}_{i}$ & & $\widehat{m}_{i}$ & & $\widehat{m}_{i}$ & $\widehat{x}_{i}$ \\
\hline 1. Ferencváros & 76 & 1 & 1,095 & 1 & 1,124 & 1 & 1,252 & 0,399 \\
\hline 2. MOL Fehérvár & 63 & 2 & 0,700 & 2 & 0,720 & 2 & 0,759 & $-0,101$ \\
\hline 3. Puskás Akadémia & 54 & 3 & 0,488 & 3 & 0,516 & 3 & 0,563 & $-0,169$ \\
\hline 4. Mezökövesd & 50 & 4 & 0,363 & 4 & 0,372 & 4 & 0,472 & $-0,217$ \\
\hline 5. Honvéd & 44 & 5 & 0,214 & 5 & 0,229 & 6 & 0,270 & $-0,156$ \\
\hline 6. Újpest & 43 & 7 & 0,148 & 7 & 0,156 & 7 & 0,228 & $-0,092$ \\
\hline 7. Zalaegerszeg & 43 & 6 & 0,203 & 6 & 0,213 & 5 & 0,281 & 0,168 \\
\hline 8. Kisvárda & 42 & 9 & 0,097 & 9 & 0,109 & 9 & 0,190 & 0,289 \\
\hline 9. Diósgyör & 41 & 10 & 0,053 & 10 & 0,074 & 10 & 0,154 & 0,126 \\
\hline 10. Paks & 41 & 8 & 0,116 & 8 & 0,136 & 8 & 0,194 & 0,274 \\
\hline 11. Debrecen & 39 & 11 & 0 & 11 & 0 & 11 & 0 & 0,290 \\
\hline 12. Kaposvár & 14 & 12 & $-0,884$ & 12 & $-0,882$ & 12 & $-0,845$ & 0,223 \\
\hline
\end{tabular}

1. táblázat. A kiértékelések eredményei

azonban a páros összehasonlítási módszerek esetén számít, hogy a Zalaegerszeg jobb csapatok ellen tudott döntetlent, illetve győzelmet elérni. A Zalaegerszeg döntetlent játszott egyszer a legerősebb Ferencvárossal, valamint kétszer megverte a 3. helyen végzett Puskás Akadémiát, így került az Újpest elé. Ez az eltérés a $T^{D E}$ modellben is megjelenik. Részben hasonló okok (a Paks győzelme a MOL Fehérvár ellen) alapján előzi meg a 10. helyezett Paks a 9. helyezett Diósgyőrt és a 8. helyezett Kisvárdát mindhárom Thurstone módszerrel történő kiértékelésnél a hivatalos sorrendhez képest. A fentieken kívül a $T^{D E}$ modellben még egy eltérés tapasztalható, a Zalaegerszeg nem csak az Újpestet előzi meg, hanem a hivatalos sorrendben kettővel előtte levő Honvédot is.

Az előny számszerűsítekor kapott számérték konstans előny esetén, azaz a $T^{K E}$ modellben 0,072 lett, ami azt jelenti, hogy a teljesítmény várható értéke ennyivel nő a modell szerint hazai pálya esetén és ugyanennyivel csökken idegen pálya esetén.

Amikor csapatonként más és más előny/hátrány származik a hazai, illetve az idegenben játszott meccsek esetén, meglepve tapasztalhatjuk több esetben is, hogy az optimum a negatív argumentumnál van! Ez azt jelenti, hogy ezeknek a csapatoknak az idegen pályán való teljesítménye átlagosan jobb, mint a hazai pályán mutatott teljesítménye. Átböngészve a részletes eredményeket tartalmazó honlapot ([14]), valóban azt tapasztaljuk, hogy ezen csapatok gyakrabban nyernek idegenben, mint hazai pályán.

Példaként álljon itt Mezőkövesd esete. A csapat otthon hét győzelem mellett elért három döntetlent és kikapott hétszer. Azonban idegenben határozottan 
jobban teljesített, mert csak négyszer kapott ki az öt döntetlen és a hét győzelem mellett. Vagyis valóban, az otthoni teljesítménye kimondottan rosszabb, mint az idegenbeli, ami összhangban van a táblázatbeli $\widehat{x}_{i}=-0,217$ értékkel.

Ezzel épp ellenkezőleg, ha megvizsgáljuk a Ferencváros meccseinek eredményét, azt láthatjuk, hogy hazai pályán a mérkőzéseit mind megnyerte három kivételével, akkor döntetlent játszott, de idegen pályán 16 mérkőzéséből három vereséggel és négy döntetlennel végződött. Ez alátámasztja a nagy, közel 0,4-es értékünek számolt többletet, amivel nő a teljesítménye hazai pályán.

Hasonlóan szemügyre véve a Kaposvár eredményeit, győzelmet csak a Diósgyőr és a Debrecen ellen tudott elérni, ezek közül három hazai, egy idegenbeli mérkőzés volt. Látható azonban, hogy a Kaposvár átlagos teljesítménye a többiekéhez képest oly kicsi, hogy még a fentiekből fakadó, átlag $(=0,086)$ feletti $\widehat{x}_{i}=0,223$ érték sem emeli a többiek fölé. Ezek a példák azt mutatják, hogy a kapott $\widehat{x}_{i}$ értékek teljes összhangban vannak a csapatok otthoni és idegenbeli mérkőzéseinek eredményével.

A becsült $\underline{m}, d$, és $\underline{e}$ paraméterek segítségével lehetőségünk nyílik az előnyben/hátrányban győzelem, döntetlen és vereség kialakulása valószínűségének becslésére az (5) és a (6) képletekbe való behelyettesítéssel. Másik becslése az említett valószínűségeknek a relatív gyakoriság. Hasonlítsuk össze kvantitatív módon ezeket a becsléseket az összes csapat esetén, illetve a legjobb csapat esetén!

\begin{tabular}{|c|c|c|c|}
\hline & Győzelem & Döntetlen & Vereség \\
\hline Relatív gyakoriság & 0,43434 & 0,22222 & 0,34343 \\
\hline$T^{K E}$ & 0,43589 & 0,22031 & 0,34380 \\
\hline$T^{D E}$ & 0,43487 & 0,22182 & 0,34331 \\
\hline
\end{tabular}

2. táblázat. Az előnyben levő csapat győzelmének/döntetlen eredményének/vereségének becsült valószínűségei

Mint a 2. Táblázatból látható, mindkét Thurstone módszer esetén a becsült valószínüségek nagyon közel esnek a relatív gyakoriságokhoz, eltéréseket csak az ezredekben tapasztalunk. Mivel az előnyben levő csapat győzelme egyben a hátrányban levő csapat veresége, a hátrányban levő csapatok szempontjából a Győzelem és a Vereség oszlopok megcserélődnek.

Vizsgálhatjuk csapatonként is a győzelem/döntetlen/vereség valószínüségének becsléseit előnyben, illetve hátrányban. A Ferencváros esetében kapott eredményeket a 3. és a 4 . Táblázatok tartalmazzák.

A 4. Táblázat alapján láthatjuk, hogy hátrányban a $T^{D E}$ modell alapján becsült valószínüségek mindhárom esetben 0,03-nál kisebb hibával közelítik a relatív gyakoriságokat, továbbá az eltérések a relatív gyakoriságok és a becsült valószínüségek között a $T^{D E}$ modell esetén jóval kisebbek, mint a $T^{K E}$ modell esetén. 


\begin{tabular}{|c|c|c|c|}
\hline & Győzelem & Döntetlen & Vereség \\
\hline Relatív gyakoriság & 0,82353 & 0,17647 & 0 \\
\hline$T^{K E}$ & 0,76674 & 0,1481 & 0,08516 \\
\hline$T^{D E}$ & 0,84667 & 0,10512 & 0,04821 \\
\hline
\end{tabular}

3. táblázat. A Ferencváros előnye esetén a csapat győzelmének/döntetlen eredményének/vereségének becsült valószínüségei

\begin{tabular}{|c|c|c|c|}
\hline & Gyözelem & Döntetlen & Vereség \\
\hline Relatív gyakoriság & 0,56250 & 0,25000 & 0,1875 \\
\hline$T^{K E}$ & 0,67539 & 0,18805 & 0,13656 \\
\hline$T^{D E}$ & 0,58742 & 0,22726 & 0,18532 \\
\hline
\end{tabular}

4. táblázat. A Ferencváros hátránya esetén a csapat győzelmének/döntetlen eredményének/vereségének becsült valószínüségei

A 3. Táblázatból azt láthatjuk, hogy előny esetén a Ferencváros győzelmének és vereségének esélye a relatív gyakorisághoz a $T^{D E}$ modell esetén van közelebb, de döntetlen esetén fordított a helyzet. Összességében azonban a csapatonkénti előny figyelembe vételével alkotott modell mutatkozik jobbnak.

\section{5. Összefoglalás}

Egy, az összehasonlítandó objektumok sorrendjét és erősségét, valamint az esetlegesen meglévő előny mértékét meghatározni képes, páros összehasonlításokon alapuló, általánosított Thurstone módszert adtunk meg cikkünkben.

Az általános megközelítés kiterjed arra, hogy a véleménykategóriák száma tetszőleges lehet, továbbá arra, hogy a módszer képes kezelni az objektumok összehasonlításakor esetleg előforduló, külső körülmények által meghatározott (objektumonkénti, vagy közös) előnyt, illetve hátrányt. Mindezeket úgy, hogy az objektumok mögött lévő látens valószínűségi változók esetében általános eloszlásfüggvénytípust engedtünk meg.

Mivel a sorrend megállapítása egy likelihood függvény maximalizálásával történik, ezért fontos, hogy sikerült a maximumhely egyértelmü létezésére széles körben használható elégséges feltételt adnunk.

Módszerünket alkalmaztuk futballbajnokság csapatai egymás elleni eredményeinek kiértékelésére, amely során a sorrend és az egyes csapatok erősségeinek meghatározásán túl számszerüsíteni tudtuk a hazai pálya előnyét (bizonyos csapatoknál inkább hátrányát) is. 


\section{Köszönetnyilvánítás}

A publikáció elkészítését, megjelenését támogatta az Innovációs és Technológiai Minisztérium a Tématerületi Kiválósági Program keretében az NKFIH-84310/2019 sz. támogatói okirat alapján. A támogatást a szerzők ezúton is köszönik. A szerzők továbbá köszönetet mondanak az EFOP-3.6.1-16-2016-00015 számú projekt anyagi támogatásáért.

\section{Hivatkozások}

[1] L.L. Thurstone: A law of comparative judgment, Psychological Review, Vol. 34 No. 4, pp. 273-286 (1927).

[2] T.L. SaAty: How to make a decision, the Analytic Hierarchy Process, European Journal of Operational Research, Vol. 48 No. 1, pp. 9-26 (1990). DOI: 10.1016/0377-2217(90)90057-I

[3] S. BozóKI, J. FÜLÖP AND L. RóNYAI: On optimal completion of incomplete pairwise comparison matrices, Mathematical and Computer Modelling, Vol. 52 No. 1, pp. 318-333 (2010). DOI: 10.1016/j.mcm.2010.02.047

[4] Temesi J.: Páros összehasonlítások a döntéshozatalban, Alkalmazott Matematikai Lapok, Vol. 37 No. 2, pp. 1-10 (2020). DOI: 10.37070/AML.2020.37.2.01

[5] R.A. Bradley And M.E. Terry: Rank analysis of incomplete block designs: I. The method of paired comparisons, Biometrika, Vol. 39 No. 3/4, pp. 324-345 (1952). DOI: $10.2307 / 2334029$

[6] H. Stern: A continuum of paired comparisons models, Biometrika, Vol. 77 No. 2, pp. 265273 (1990). DOI: $10.2307 / 2336804$

[7] É. Orbán-Mihálykó, C. Mihálykó AND L. Koltay: Incomplete paired comparisons in case of multiple choice and general log-concave probability density functions, Central European Journal of Operations Research, Vol. 27 No. 2, pp. 515-532 (2019). DOI: $10.1007 / \mathrm{s} 10100-018-0568-1$

[8] Mihálykóné Orbán É. And Mihálykó Cs.: A Thurstone módszer általánosítása elönyök figyelembe vételére, Szigma, Vol. 52 No. 1, pp. 49-62 (2021).

[9] É. Orbán-Mihálykó, C. Mihálykó And L. Koltay: A generalization of the Thurstone method for multiple choice and incomplete paired comparisons, Central European Journal of Operations Research, Vol. 27 No. 1, pp. 133-159 (2019). DOI 10.1007/s10100-017-0495-6

[10] A. PRÉKOPA: Logarithmic concave measures and functions, Acta Scientiarum Mathematicarum, Vol. 34 No. 1, pp. 334-343 (1973).

[11] Mihálykóné Orbán É., Mihálykó Cs. És Kajtár P.: Általánosított Thurstone módszer alkalmazásokkal, Alkalmazott Matematikai Lapok, Vol. 36 No. 2, pp. 255-262 (2019). DOI: 10.37070/AML.2019.36.2.09

[12] MihÁlykóné OrbÁn É. És Mihálykó Cs.: Elégséges feltétel a maximum likelihood becslés létezésére és egyértelmüségére bizonyos Thurstone módszerek esetében (kézirat)

[13] https://allsportsapi.com, letöltés: 2020. szeptember 30.

[14] https://focimagazin.hu/otp-bank-liga-nb1-201920-eredm\%C3\%A9nyek-tabella letöltés: 2021.01.21. 


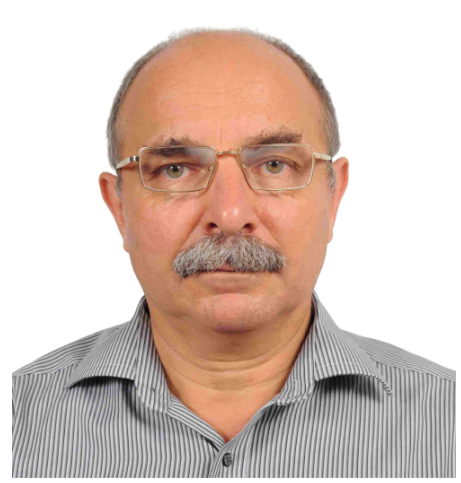

Dr. Mihálykó Csaba 1962-ben született Veszprémben. 1987-ben szerzett az Eötvös Loránd Tudományegyetemen okleveles matematikus végzettséget, majd 1996-ban alkalmazott matematika területén PhD-t ugyanott. 1994-ben Farkas Gyula emlékdíjat, 2000-ben Bolyai János Kutatási Ösztöndíjat, 2019-ben Mestertanár Aranyérmet kapott. 1987 óta dolgozik Veszprémben a Pannon Egyetemen, illetve jogelődjein, jelenleg a Matematika Tanszéken egyetemi docensként. Kutatási területei: kockázati folyamatok, döntéselmélet, matematikai modellezés. Eddig több mint 150 tudományos közleménye jelent meg, ezek közül 55 tudományos folyóiratban. Összes független hivatkozásainak száma meghaladja a 250-t, Hirsch-indexe 8.

\section{MIHÁLYKÓ CSABA}

Pannon Egyetem, Müszaki Informatikai Kar, Matematika Tanszék,

Veszprém, Egyetem u. 10. H8200.

mihalyko@almos.uni-pannon.hu

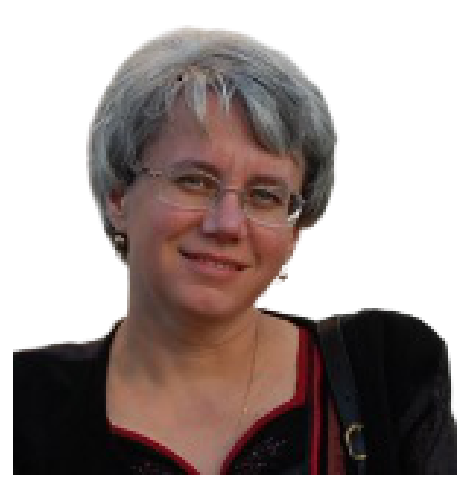

Dr. Mihálykóné dr. Orbán Éva 1964-ben született Pápán, és 1987-ben végzett az ELTE matematikus szakán. 1991-ben egyetemi doktori címet, 2004-ben PhD fokozatot szerzett. 1987 óta a veszprémi egyetem (ma Pannon Egyetem) Matematika Tanszékén oktat főként valószínüségszámítást és matematikai statisztikát, jelenleg egyetemi docensi beosztásban. Kutatási területe a sztochasztikus modellek témaköre. 2020-ig bezárólag több, mint 70 publikációja jelent meg, melyek közül 33 referált folyóiratcikk. Munkáira több, mint 120 hivatkozást kapott, Hirsch-indexe 6.

\section{MIHÁLYKÓNÉ ORBÁN ÉVA}

Pannon Egyetem, Műszaki Informatikai Kar,

Matematika Tanszék,

Veszprém, Egyetem u. 10. H8200.

orbane@almos.uni-pannon.hu 


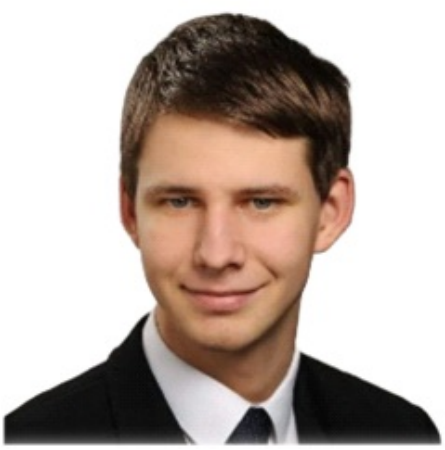

Gyarmati László 1996-ban született Veszprémben. BSc tanulmányait a Pannon Egyetem Müszaki Informatika Karának programtervező informatikus szakán végezte, és 2020-ban megszerezte diplomáját. Diplomájának témája a Thurstone módszer alkalmazása rangsorolásra két és négy kategória esetén elöny nélküli, konstans és csapatonkénti előnyös modellek segítségével. Már az egyetem utolsó félévében a Secudit Kft.-nél dolgozott részmunkaidőben, ezt teljes állásban folytatta 2020 második felében. Munkája során a Windows sebezhetőségeivel foglalkozott, és matematikai modellt hozott létre gépek sebezhetőségének pontszámmal való értékelésére.

\section{GYARMATI LÁSZLÓ}

Pannon Egyetem, Müszaki Informatikai Kar, Veszprém, Egyetem u. 10. H8200 xdktdk96@gmail.com

\section{ON THE GENERALIZATIONS OF THE THURSTONE METHOD \\ Csaba Mihálykó, Éva Orbán-Mihálykó, LÁszló Gyarmati}

Paired comparisons are often used in decision making to evaluating opinions, but the results of sport matches can also be regarded as paired comparisons. Several methods can be applied for evaluations. One of the possible methods is the Thurstone's method. It is based on the idea of latent random variables and it uses probabilistic method for the evaluations. This method is appropriate to build in possible advantages/disadvantages. In this paper we present a Thurstone model with arbitrary number of categories and with the possibility of advantage/disadvantages. We apply it for evaluating football results.

Keywords: paired comparison, Thurstone method, maximum likelihood estimation, advantages/disadvantages.

Mathematics Subject Classification (2000): 62J15, 62H15 